\title{
STABILITY ANALYSIS OF STEEL FRAME STRUCTURES: P-DELTA
}

\section{ANALYSIS}

\author{
Mallikarjuna B.N ${ }^{1}$, Ranjith $\mathbf{A}^{2}$ \\ ${ }^{\text {I}}$ P.G. Student, Department of Civil Engineering, AIT, Chikmagalur, Karnataka, India \\ ${ }^{2}$ Assistant Professor, Department of Civil Engineering, AIT, Chikmagalur, Karnataka, India
}

\begin{abstract}
The high rise buildings require high frame structure stability for safety and design purposes. This research focused on P-delta analysis to be compared with linear static analysis. In this study, a 18 storey steel frame structure with $68.9 \mathrm{~m}$ has been selected to be idealized as multi storey steel building model. The model is analyzed by using STAAD.Pro 2007 structural analysis software with the consideration of P-delta effect. At the same time the influence of different bracing patterns has been investigated. For this reason five types of bracing systems including $X, V$, Single Diagonal, Double $X, K$ bracing with unbraced model of same configuration are modeled and analyzed. The framed structure is analyzed for Wind load as per IS 875 (part 3)-1987. After analysis, the comparative study is presented with respective to Maximum storey displacement and Axial Force. The present work showed that the 'X'bracing in continuous bracing pattern is proved to be more effective with respect to both Static and P-delta analysis.
\end{abstract}

Keywords: Wind load, Displacement, Axial force, P-delta analysis, Bracings.

\section{INTRODUCTION}

Tall building is the most structure that requires stability because it consists a lot of frame structure with different width and height. Buildings and structures are considered stable with lateral supports by using either bracing systems or shear system or both such as wall to ensure the stability of the building. Moreover, the important thing to consider are the software to be used for the analysis of tall building structure and wind speed at construction area to avoid any problems in future.

There have been so many cases in which the structures failed due to instability which require P-Delta analysis. One of the problems is affected from wind load. Wind creates inward and outward pressures acting on building surfaces, depending on the orientation of the surface such as flat. This pressure increases uplift on parts of the building, forcing the building apart if it is too weak to resist the wind loads. Therefore, the most important thing to overcome this problem is the connection between beam and column in a frame such as rigid or pin ended should be considered for a realistic design it will become instable structure which means loss of some situation and come close to a failure such as buckling and sway if the structure cannot sustain for a certain load whether from dead load, imposed load, wind load and also natural phenomena like earthquake.

VISWANATH K.G et al. [1] has investigated on the seismic performance of reinforced concrete (RC) buildings rehabilitated using concentric steel bracing and also the performance of the building was evaluated in terms of global and storey drifts. For this purpose a four storey building was modeled. The buildings were modeled as a series of load resisting elements. The lateral loads to be applied on the buildings are based on the Indian standards. The study was performed for seismic zone 4as per IS 1893: 2002. The effect of the distribution of the steel bracing along the height of the RC frame on the seismic performance of the rehabilitated building was studied. In this study the frames were assumed to be firmly fixed at the bottom and the soil-structure interaction is neglected. From the result they concluded that the use of steel bracing is one of the advantageous concepts which can be used to strengthen or retrofit the existing structures. Steel bracings reduce flexure and shear demands on beams and columns and transfer the lateral loads through axial load mechanism. From the results it was found that $\mathrm{X}$ type of bracing systems will greatly reduce the lateral displacements and also minimum possible bending moments in comparison to other type of bracing systems.

\subsection{Bracing Systems}

Steel braced frame is one of the structural systems used to resist lateral loads in multistoried buildings. Steel bracing is economical, easy to erect, occupies less space and has flexibility to design for meeting the required strength and stiffness. Braced frames are often used to resist lateral loads but braces can interfere with architectural features. The steel braces are usually placed in vertically aligned spans. This system allows obtaining a great increase of stiffness with a minimal added weight, so it is very effective for existing structure for which the poor lateral stiffness is the main problem. Bracings are usually provided to increase stiffness and stability of the structure under lateral loading and also to reduce lateral displacement significantly. 


\section{DETAILS OF THE STRUCTURE}

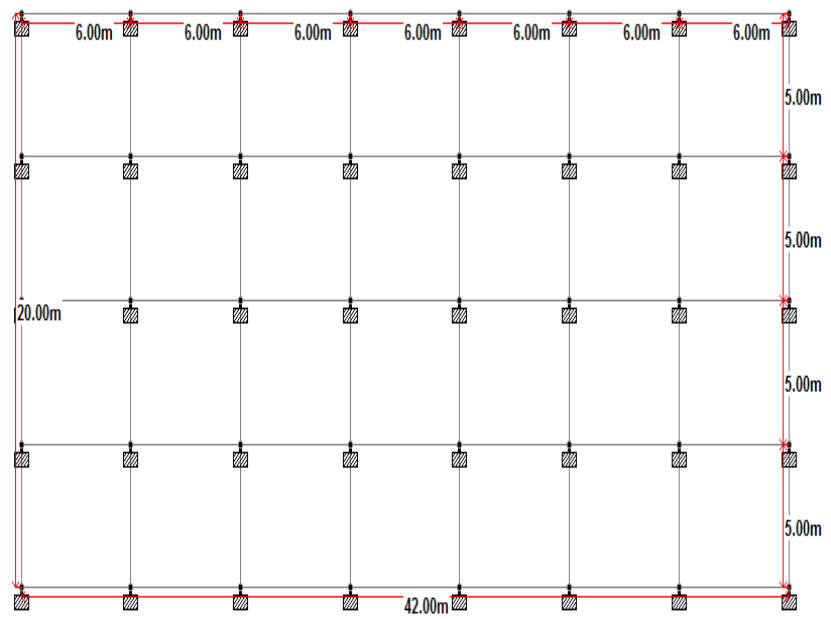

Fig.1: Plan of building

Following types of bracings are considered for the analysis:

1. Without Bracing

2. Single-Diagonal

3. X Bracing

4. Double X Bracing

5. K Bracing

6. V Bracing

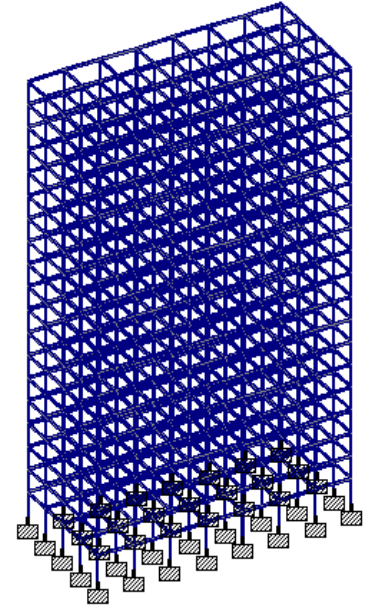

Fig.2: Unbraced Steel building system

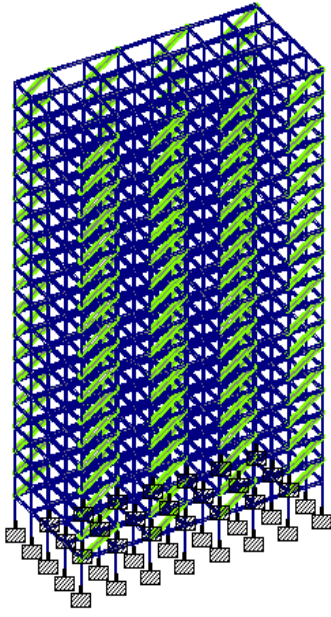

Fig.3: Single Diagonal Bracing
Table 1: Building plan detail

\begin{tabular}{|l|l|}
\hline Type & Commercial building \\
\hline Plan dimension & $: 42 \mathrm{~m} \mathrm{x20} \mathrm{m}$ \\
\hline Height of Storey & $: 3.6 \mathrm{~m}$ \\
\hline Wind zone & $: 2$ \\
\hline Location & $:$ Mangalore \\
\hline Basic wind speed & $: 39 \mathrm{~m} / \mathrm{sec}$ \\
\hline Beam & $:$ ISWB 400 \\
\hline Column & $:$ ISMB 200 \\
\hline Bracings & \\
\hline
\end{tabular}
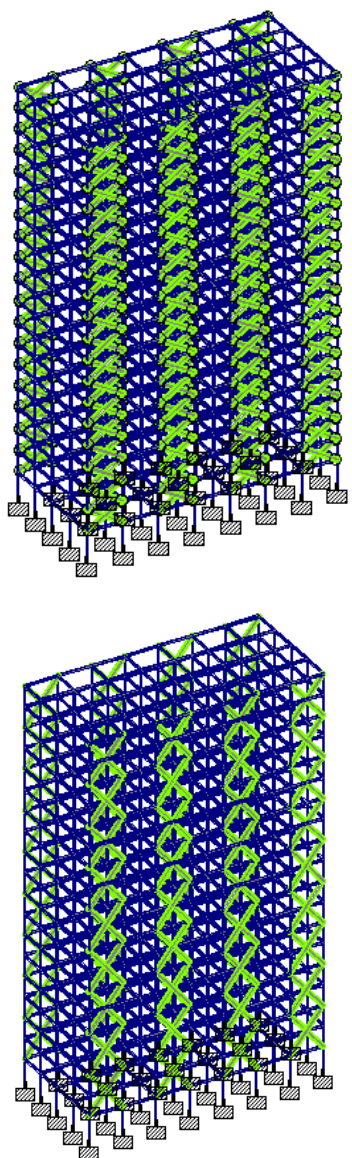

Fig.4: X bracing system

Fig.5: Double x type bracing system

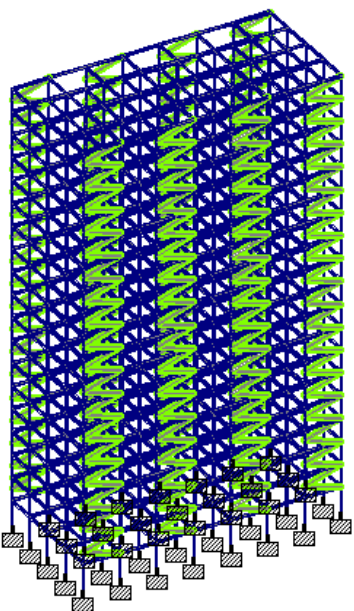

Fig.6

$\mathrm{K}$ type bracing system

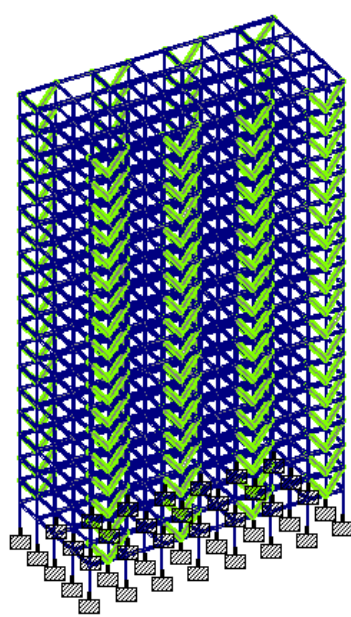

Fig.7

V type bracing system

\section{LOAD CALCULATION}

\subsection{Gravity Load}

The loads considered for the following study are as below which are according to the IS codes.

1. Dead load: The self weight of the structural members is calculate according to the code provisions and is taken care in the software. 
2. Live load on floor: $4 \mathrm{kN} / \mathrm{m}^{2}$ (Table 1 of IS 875 (Part-2) :1987)

\subsection{Wind Load}

Wind load calculations as per Indian code: IS 875 (Part-3)1987

Design wind speed (Vz) can be mathematically expressed as follows

$$
\mathbf{V}_{\mathrm{z}}=\mathbf{V}_{\mathrm{b}} \cdot \mathbf{k}_{\mathbf{1}} \cdot \mathbf{k}_{\mathbf{2}} \cdot \mathbf{k}_{\mathbf{3}}
$$

Wind load on individual members ( $\mathbf{F}$ ) is given by

$$
F=\left(C_{p e}-C_{p i}\right) A . P_{d}
$$

\section{RESULTS AND DISCUSSIONS}

\subsection{Displacement for Continuous Type Bracing}

\section{Systems}

Table 2: Displacement for continuous type bracing Systems

\begin{tabular}{|l|l|l|}
\hline Type of Bracing & Static analysis & P-delta analysis \\
\hline Unbraced & 412.496 & 837.974 \\
\hline X Bracing & 167.361 & 294.47 \\
\hline V Bracing & 177.088 & 298.097 \\
\hline Single Diagonal & 172.804 & 375.248 \\
\hline $\begin{array}{l}\text { Double X } \\
\text { Bracing }\end{array}$ & 169.752 & 297.385 \\
\hline K Bracing & 186.845 & 320.83 \\
\hline
\end{tabular}

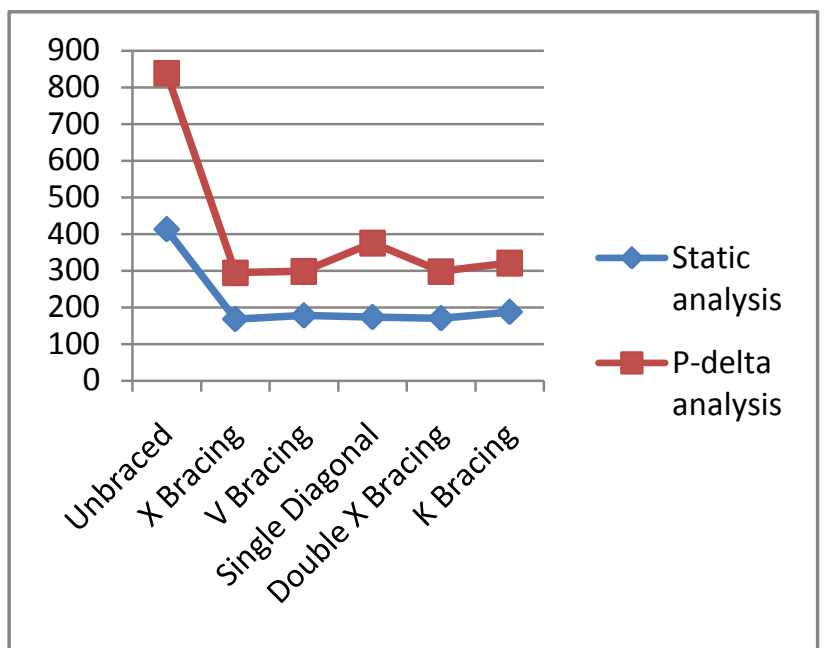

Chart 1: Variations of Maximum Displacements

Chart-1 shows variation of Maximum Displacements for Static and P-Delta analysis for different Bracing systems. From the above graph it is observed that for $\mathrm{X}$ type bracing gives less Displacement value as compared to other types of bracing in both the methods of analysis.

\subsection{Displacement for Alternate Type Bracing}

\section{Systems}

Table 3: Displacement for Alternate type bracing Systems

\begin{tabular}{|l|l|l|}
\hline Type of Bracing & Static analysis & P-delta analysis \\
\hline X Bracing & 304.331 & 584.459 \\
\hline V Bracing & 305.435 & 563.986 \\
\hline Single Diagonal & 300.501 & 601.299 \\
\hline $\begin{array}{l}\text { Double X } \\
\text { Bracing }\end{array}$ & 302.123 & 580.389 \\
\hline K Bracing & 312.446 & 598.246 \\
\hline
\end{tabular}

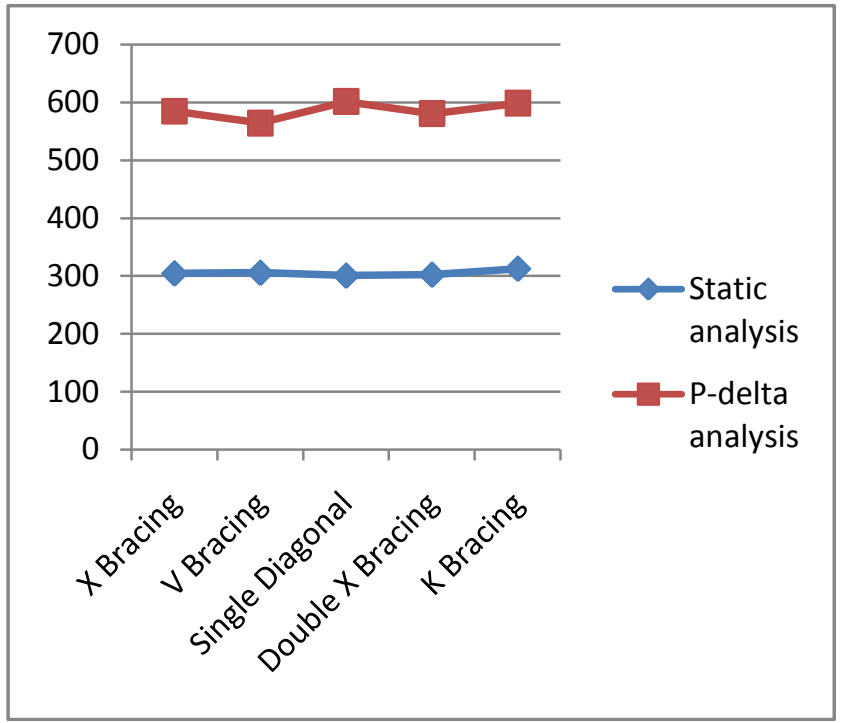

Chart 2: Variations of Maximum Displacements

Chart-2 shows variation of Maximum Displacements for Static and P-Delta analysis for different Bracing systems. From the above graph it is observed that for $\mathrm{V}$ type bracing gives less Displacement value as compared to other types of bracing in both the methods of analysis.

\subsection{Axial Force for Continuous Bracing Systems}

Table 4: Axial Force for Continuous Bracing Systems

\begin{tabular}{|l|l|l|}
\hline Type of Bracing & Static Analysis & P-delta analysis \\
\hline Unbraced & 1080 & 2320 \\
\hline X Bracing & 2220 & 2710 \\
\hline V Bracing & 1220 & 2650 \\
\hline Single Diagonal & 1200 & 2650 \\
\hline $\begin{array}{l}\text { Double X } \\
\text { Bracing }\end{array}$ & 1310 & 2750 \\
\hline K Bracing & 1240 & 2640 \\
\hline
\end{tabular}




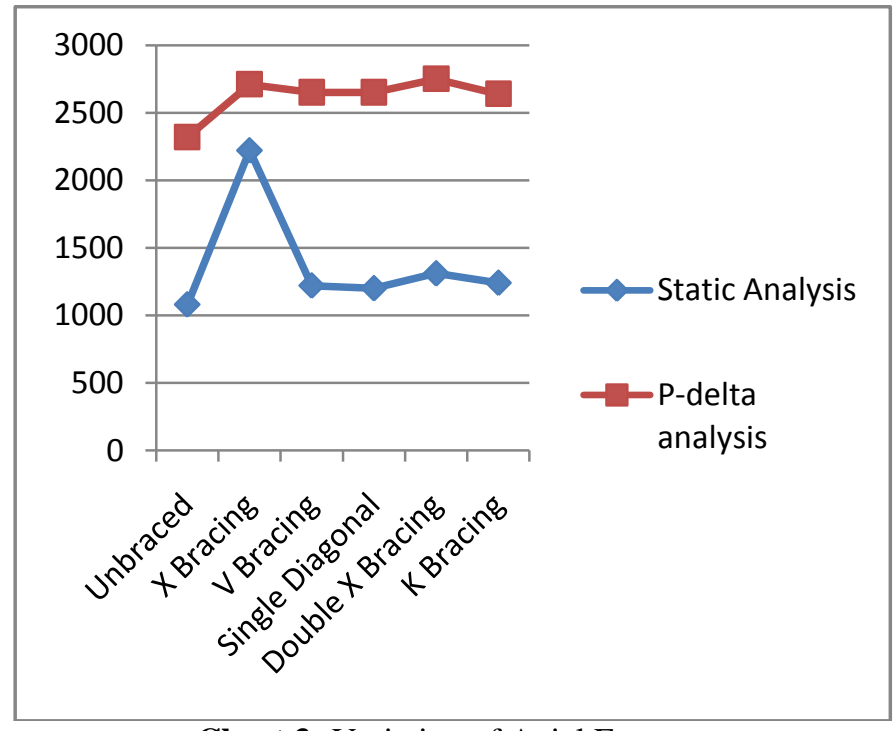

Chart 3: Variation of Axial Force

Chart-3 shows variation of Maximum Axial Force for Static and P-Delta analysis for different Bracing systems. From the above graph it is observed that for $\mathrm{X}$ type bracing gives high axial load as compared to other types of bracing in both the methods of analysis.

\subsection{Axial Force for Alternate Bracing system}

Table 5: Axial Force for Alternate Bracing system

\begin{tabular}{|l|l|l|}
\hline Type of Bracing & Static Analysis & P-delta analysis \\
\hline X Bracing & 1230 & 2550 \\
\hline V Bracing & 972.162 & 2550 \\
\hline Single Diagonal & 1190 & 2510 \\
\hline Double X Bracing & 1250 & 2600 \\
\hline K Bracing & 1190 & 2500 \\
\hline
\end{tabular}

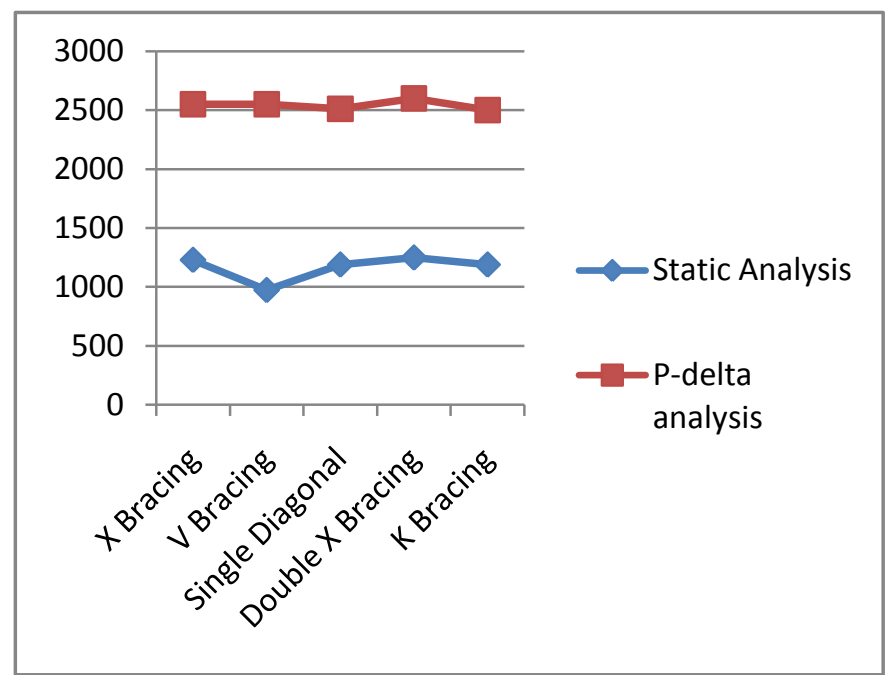

Chart 4: Variation of Axial Force
Chart-4 shows variation of Maximum Axial Force for Static and P-Delta analysis for different Bracing systems. From the above graph it is observed that for Double $\mathrm{X}$ type bracing gives high axial load as compared to other types of bracing in both the methods of analysis.

\section{CONCLUSIONS}

On the basis of the present study, following conclusions are made:

$>\quad$ The second order effects found to increase the storey displacements at all level of the structure. Compare to the structure subjected to other than second order effects.

$>\quad$ The concept of using Steel bracing is one of the advantageous concepts to strengthen or to retrofit the existing structure. From the results was found that storey displacement of the building are greatly reduced by the use of Concentric (X) bracing in comparison to Eccentric bracings.

$>\quad$ The interstorey drifts greatly reduced in presence of Continuous bracing system in comparison to Alternative bracing even the second order or PDelta effects are considered.

$>\quad$ The displacement value for P-delta analysis is increases from 70 to $75 \%$ for Continuous type bracing and 85 to $95 \%$ for Alternative type bracing has compared to static analysis.

$>\quad$ The Axial Force for Continuous type in P-delta analysis is increase $22 \%$ has compared to static analysis. The value of Axial Force increased twice more for other bracings in case of P-delta analysis.

$>\quad$ The value of Axial Force for Alternative type in Pdelta analysis is twice more has compared to static analysis.

\section{REFERENCES}

[1] DAVIDSON B. J, FENWICK R.C CHUNG B.T, "Pdelta effects in multi-storey structural design" Earthquake Engineering, Tenth World conference at Balkema, 1992

[2] JAGADISH J.S, TEJAS D. DOSHI, "A Study on Bracing Systems on High Rise Steel Structures" International Journal of Engineering Research and Technology, Volume 2, July 2013.

[3] SHAMSHINAR BINTI SALEHUDDIN, "Stability of a Six Storey Steel Frame Structures" UniversitiTeknologiMalasiya, May 2011.

[4] SURESH P, PANDURANGA RAO B, KALYANA RAMA J.S, "Influence of Diagonal Braces in RCC Multi-Storied Frames under Wind Loads"International Journal of Civil and Structural Engineering, Volume 3, No 1, 2012.

[5] IS: 875 (Part 1)-1987 Code of practice for design loads (Other than Earthquake) for buildings and structures, Bureau of Indian Standard, New Delhi, India.

[6] BIS Code, IS 875 (Part 2)-1987. “Code of Practice for design loads (other than earthquake) for building 
and structure", Part 2, Imposed loads. BIS,

ManakBhawan, New Delhi, India.

[7] BIS Code, IS 875 (Part 3)-1987, "Code of Practice for design loads (other than earthquake) for building and structure", Part 3, Wind Loads, BIS, ManakBhawan, New Delhi, India.

[8] IS 802 (Part 1/Sec 1):1995 and IS 802 (Part 1/Sec):1992, "Use of Structural Steel in Overhead Transmission Line Tower - code of Practice.

[9] "Design of Steel Structures" by Prof. S.R. Satish Kumar and Prof. A.R. Santha Kumar.

\section{BIOGRAPHIE}

Mallikarjuna B N, M.tech in Structural Engineering AIT

Chickmaglur, Contact No-9844040692. 